\title{
PASTORAL KONSELING PSIKOLOGI ALKITABIAH BAGI PEREMPUAN YANG TELAH MELAKUKAN HUBUNGAN SEKS SEBELUM MENIKAH
}

\author{
Junius Halawa
}

\section{PENDAHULUAN}

Manusia adalah makhluk ciptaan Allah yang unik dan mulia. Kejadian 1:26 "Berfirmanlah Allah: Baiklah Kita menjadikan manusia menurut gambar dan rupa Kita.” Allah adalah inisiator untuk menciptakan manusia. Allah juga yang merancang bentuk (grand design) manusia itu diciptakan. Allah menetapkan bahwa manusia diciptakan "segambar" dan "serupa" dengan diri-Nya sendiri. Istilah tersebut tidak dimaksudkan keadaan secara jasmani, lebih tepat dipahami kesamaan sifat Allah yang dimiliki oleh manusia. ${ }^{1}$

Fakta menunjukkan bahwa diera ini, seks seringkali disalah artikan sehingga menimbulkan perilaku seksual yang menyimpang. Zaman ini dikenal dengan era globalisasi. ${ }^{2}$ Sehubungan dengan fakta tersebut, Penelitian Universitas Indonesia dan Australian National University tahun 2010 menyebutkan, sebanyak 20,9 \% remaja putri di Indonesia telah hamil di luar nikah karena seks bebas dan 38,7 \% telah Survei BKKBN tahun 2011 menyebutkan, $51 \%$ remaja putri di kota-kota besar tidak perawan lagi. Terbaru, Survei Data Demografi dan Kesehatan Indonesia (SDKI) 2012 menyebutkan, jumlah remaja yang melahirkan sebanyak $48 \%$ remaja putri. Padahal, pada tahun 2007 lalu, jumlah remaja yang melahirkan ini hanya sebanyak 35 orang dari 1.000 orang remaja putri. ${ }^{3}$

Oleh karena itu, pelayanan pastoral konseling Kristen harus dilakukan secara efektif agar dapat menolong para korban dan secara bersamaan Berdasarkan persoalah yang inilah penulis tergerak serta didorong untuk meneliti dan menulis karya ilmiah ini yang berjudul: "Pastoral Konseling Psikologi Alkitabiah Bagi Perempuan Yang Telah Melakukan Hubungan Seks Sebelum Menikah.

\footnotetext{
${ }^{1}$ Hanry C. Thiessen, Teologi Sistimatika, (Malang: Gandum Mas, 2008), 235

${ }^{2}$ Globalisasi adalah suatu proses yang menyeluruh atau mendunia dimana setiap orang tidak terikat oleh negara atau batas-batas wilayah, artinya setiap individu dapat terhubung dan saling bertukar informasi dimanapun dan kapanpun melalui media elektronik

${ }^{3} \mathrm{http}: / /$ lampung.tribunnews.com, (Senin, 17 April 2017)
} maupun cetak. 


\section{Hakikat Pastoral Konseling Psikologi Alkitabiah}

\section{$\underline{\text { Etimologis }}$}

Istilah "pastoral berasal dari kata "pastor" dalam bahasa Latin atau bahasa Yunani disebut "poimen", yang berarti "gembala, pendeta". 4 Seorang gembala mempunyai tugas menggembalakan warga gereja atau domba-domba Allah yang dipercayakan kepadanya (Yohanes 10:11; Yohanes 21:15).

Istilah konseling berasal dari bahasa Latin, yaitu: "concilium" yang berarti "dengan" atau "bersama" yang dirangkai dengan "menerima" atau "memahami". 5 Maka, pastoral konseling ialah interaksi yang terjadi antara dua orang individu, masing-masing disebut konselor dan klien.

Istilah "konselor" dalam bahasa Inggris counselor atau helper merupakan petugas khusus yang berkualifikasi dalam bidang konseling (counseling). ${ }^{6}$ Jadi, konselor adalah seorang yang memiliki keahlian dalam bidang pelayanan konseling, ia sebagai tenaga profesional.

Istilah "klien" (konseli), dalam bahasa Inggris disebut clinent, adalah individu yang memperoleh pelayanan konseling. ${ }^{7}$ Klaien adalah seorang atau kelompok individu yang mengalami masalah, sehingga mereka membutuhkan bantuan konseling agar mampu menghadapi, memahami, dan memecahkan masalah mereka.

\section{Dasar Alkitab Pastoral Konseling}

\section{Dasar Antropologis}

Dalam dunia psikologi sekuler, sering terjadi ketimpangan dan ketidak seimbangan dalam memandang dan memaknai kodrat manusia yang multidimensi adanya. Sebagaimana dituliskan oleh Stanley Heath, yaitu; Sejak dahulu para perintis psikologi berpola "reduktionis" (bersifat atomis), yaitu mengusahakan pengertian keseluruhan berdasarkan fungsi dan struktur bagian-bagian pilihan. Di sinilah letaknya kelemahan dari banyak "penemuan" psikologi. Alat indera dan alat pikir masing-masing diselidiki dan fungsinya dianalisa sendiri-sendiri. Relasi satu bagian dengan yang lainnya kurang mendapat perhatian. ${ }^{8}$

Pemisahan tersebut menyebabkan manusia hanya diberlakukan sebatas mahkluk hidup tanpa dimensi spiritual, sehingga berakibat pengabaian pada kebutuhannya dalam dimensi tersebut. Inilah yang sering diabaikan dalam psikologi dan konseling sekuler. 2008), 99

\footnotetext{
${ }^{4}$ Barclay M. Newman Jr, Kamus Yunani-Indonesia, (Jakarta: BPK Gunung Mulia, 2005), 136

${ }^{5}$ Prayitno \& Erman Amti, Dasar-dasar Bimbingan Dan Konseling, (Jakarta: Rineka Cipta,

${ }^{6}$ Zainal Aqib, Konseling Kesehatan Mental, (Bandung: Yrama Widya, 2013), 132

${ }^{7}$ Ibid., 136

${ }^{8}$ W. Stanley Heath, Psikologi Yang Sebenarnya, (Yogyakarta: Andi, 1995), 46-47
} 
Dalam konseling Kristen manusia harus dipandang dalam keutuhannya sebagai mahkluk jasmani, psikologis dan spiritual. Sebagaimana dikutip oleh Gary Collins dalam buku "The Rebuilding of Psychology" bahwa:

Alkitab menyajikan pendekatan yang holistik dalam memandang manusia. Manusia bukan saja dipandang dari segi fisik, rasional, emosional dan sosial, tapi juga dari sudut rohaniah, yang diciptakan dalam gambar ilahi dan diberi tempat khusus di alam ini. Tambahan lagi, Alkitab juga berbicara tentang pengampunan bagi manusia, sifat manusia yang cenderung pada dosa dan adanya jaminan yang cerah dan bersifat kekal bagi manusia. Tentu saja hal ini tidak dapat ditemukan secara empiris atau rasional sekalipun. ${ }^{9}$

Kejadian 2:7 tertulis: "Ketika itulah TUHAN Allah membentuk manusia itu dari debu tanah dan menghembuskan nafas hidup ke dalam hidungnya, demikianlah manusia itu menjadi makhluk hidup". Teks ini menerangkan mengenai hakikat dan natur manusia seutuhnya. Manusia dibentuk Allah dari debu (dimensi fisik, sosial), lalu kemudian Allah menghembusi nafas-Nya sehingga manusia menjadi hidup (dimensi rohani).

\section{Dasar Bibliologis}

Dasar lain yang tidak boleh diabaikan dalam pastoral konseling Kristen ialah memegang teguh Alkitab sebagai kebenaran final. Sebagaimana tertulis dalam 2 Tim.3:16 "Segala tulisan yang diilhamkan Allah memang bermanfaat untuk mengajar, untuk menyatakan kesalahan, untuk memperbaiki kelakukan dan untuk mendidik orang dalam kebenaran". Teks ini menegaskan bahwa firman Tuhan memainkan peranan penting dalam pastoral konseling. Alkitab adalah dasar dari semua nasehat atau saran dari konselor kepada konseli. Sehubungan dengan hal ini, Yakub B. Susabda menegaskan bahwa:

Dalam pelayanan konseling, hamba Tuhan maupun konselor Kristen akan berhadapan dengan banyak konseli yang tidak sadar bahwa kebutuhan hidupnya selama ini tidak sesuai dengan imannya sebagai orang Kristen. ${ }^{10}$ Keluhan dan persoalan yang mereka hadapi sering kali menyingkapkan realita kehidupan seperti itu. Penyebab utamanya adalah karena mereka pada umumnya tidak mempunyai pengenalan yang cukup tentang Alkitab. Oleh karena itu, tugas utama konselor adalah menolong konseli masuk dalam condusive atmosphere, untuk dapat menyadarkan konseli atas ada kebutuhan yang tidak sehat atau tidak sesuai dengan konseli sebagai orang Kristen, agar ia dapat melihat tujuan hidupnya dan

\footnotetext{
${ }^{9}$ Gary Collins, The Biblical Basis Of Christian Counseling For People Helpers, (Singapore: Methodist Book Room PTE LTD, 1993), 151-152

${ }^{10}$ Misalnya, jenis pekerjaan yang ia kerjakan (yang membuat dirinya terus-menerus terlibat dengan suap-menyuap), pola hidupnya sehari-hari yang hedonistik, pergaulannya, pengisian leasure time yang sia-sia, dan sebagainya.
} 
mengambil tindakan konkret untuk mencapai tujuan itu sesuai dengan prinsip kebenaran Alkitab. ${ }^{11}$

Jadi, Alkitab adalah standar final atau tolok ukur dari dan bagi pelayanan pastoral konseling Kristen yang benar. Alkitab memberi petunjuk, arah, tuntunan, serta hikmat bagi konselor untuk melaksanakan pelayanannya.

\section{Dasar Kristologis}

Yesus Kristus sebagai pusat dari semua ilmu teologi (Kristosetris). Pastoral konseling adalah bagian dari ilmu teologi. Hal ini menegaskan bahwa dalam pelayanan pastoral konseling harus menempatkan Kristus sebagai pusat dari semua percakapan. Rasul Paulus menuliskan dalam Kolose 1:28 "Dia yang kami beritakan, apabila tiap-tiap orang kami nasehati dan tiap-tiap orang kami ajari dalam segala hikmat, untuk memimpin tiap-tiap orang kepada kesempurnaan dalam Kristus". Rasul Paulus menyatakan bahwa ketika ia memberitakan injil, menasihati dan mengajar orang, tujuannya adalah untuk memimpin mereka kepada kesempurnaan dalam Kristus. Oleh sebab itu, Kristus dan kasih-Nya yang kekal adalah fondasi utama bagi pastoral konseling Kristen. Disini pastoral konseling Kristen menempatkan kasih Kristus sebagai dasar kekuatan dan hikmat Allah yang memotori sikap serta pelayanan konselor untuk menolong menyelesaikan permasalahan konseli sebagai manusia berdosa sampai ke akar-akarnya.

\section{Dasar Pneumatologis}

Subjek utama dari konseling Kristen adalah Roh Kudus yang bekerja selaras dengan Firman Tuhan. Peran Roh Kudus dalam proses konseling Kristen merupakan sentral dan terutama. Magdalena Tomatala mengemukakan bahwa dalam proses konseling Kristen, Roh Kudus berperan sebagai penuntun dan Firman Allah memberi terang dan hikmat terhadap persoalan yang dihadapi serta dalam memperoleh jalan penyelesaiannya. $^{12}$

Roh Kudus adalah dinamika konseling Kristen. Dalam konseling Kristen, Roh Kudus menuntun konselor Kristen untuk melayani dan sekaligus memulihkan, mengubah serta mendewasakan konseli. Dalam hubungannya dengan penyelesaian masalah, konseling Kristen bukan hanya bergantung pada kehendak manusia untuk bertanggungjawab, melainkan juga pada kuasa Roh Kudus yang berdiam di dalam

diri orang percaya yang memampukannya menaklukkan masalah manusia. ${ }^{13}$ Oleh karena itu, dalam percakapan pastoral konseling harus membiarkan Roh Kudus bekerja seluas-luasnya.

11 Yakub B. Susabda, Konseling Pastoral - Pendekatan Konseling Pastoral Berdasarkan Integrasi Teologi dan Psikologi..., 54-55

12 Magdalena Tomatala, Konselor Kompeten-Pengantar Konseling Terapi Untuk Pemulihan, (Jakarta: YT Leadership Foundation, 2000), 5

${ }^{13}$ Paul D. Meiler, Pengantar Psikologi \& Konseling Kristen 2, (Yokyakarta: Andi, 2004), 188 


\section{Tujuan Pastoral Konseling}

Tujuan utama dalam konseling Kristen adalah menolong seseorang menyelesaikan persoalan demi memenuhi tujuan mula-mula Allah dalam hidupnya, yakni menjadi serupa dengan Kristus bagi kemuliaan Bapa di Sorga (Rm. 8:29, II Kor.3:18, Yes. 43:7). Senada dengan hal ini, Larry Crabb dalam buku Konseling yang Efektif dan Alkitabiah, juga menyebutkan bahwa sasaran dari koseling yang benar ialah: "untuk mendekatkan orang-orang sehingga dapat menyembah dan melayani Allah dengan lebih baik dengan menolong mereka menjadi seperti Tuhan". ${ }^{14}$ Selanjutnya Tulus Tu'u merumuskan ada 10 (sepuluh) tujuan pastoral konseling, yakni: 1. Mencari yang hilang; 2. Menolong yang membutuhkan uluran tangan; 3 . Mendampingi dan membimbing; 4. Berusaha menemukan solusi; 5. Memulihkan kondisi yang rapuh; 6. Perubahan sikap dan perilaku; 7. Menyelesaikan dosa melalui Kristus; 8. Pertumbuhan iman; 9. Terlibat persekutuan jemaat; 10. Mampu menghadapi perseolan selanjutnya. ${ }^{15}$ Oleh karena itu, konselor Kristen harus memiliki pola pikir memuridkan terhadap konseli agar pada akhirnya konseli dapat bertumbuh dan dewasa di dalam Kristus melalui segala persoalan yang dihadapi dan bimbingan yang diberikan oleh konselor.

\section{Fungsi Pastoral Konseling}

Pelayanan pastoral pada dasarnya merupakan pelayanan yang berfungsi untuk memelihara dan memperdulikan keadaan orang lain yang memiliki masalah. Berkenaan hal tersebut, fungsi dari pastoral konseling Kristen menurut William A. Clebsch dan Charles R. Jaekle sebagaimana dikutip oleh Howard Clinebell, yaitu: menyembuhkan (healing), menopang (sustaining), membimbing (guiding), mendamaikan (reconciling) dan memelihara (nurturing). ${ }^{16}$ Dengan demikian, pastoral konseling alkitabiah memiliki fungsi untuk membawa manusia mengalami pembaharuan hidup menuju kesempurnaan seperti Yesus Kristus.

\section{Penerapan Pastoral Konseling}

Analisis dan diagnosis konselor tidak akan tepat jikalau konseli tidak menyingkapkan dirinya, kerena tidak merasakan adanya kebebasan untuk mengekspresikan perasaan dan pikirannya. Dalam kaitan ini, Yakub B. Susabda, mengemukakan ada enam unsur-unsur utama yang harus diketahui oleh konselor supaya dapat terciptanya suasana konseling yang ideal, yakni:

Pertama, Understanding (sikap penuh pengertian dari pihak konselor). Kedua, Emphaty (sikap positf konselor terhadap konsel yang diekspresikan melalui kesediaan dan kemampuannya untuk

\footnotetext{
${ }^{14}$ Larry Crabb, Konseling Yang Efektif Dan Alkitabiah, (Yogyakarta: Andi, 2011), 17

${ }^{15}$ Tulus Tu'u, Dasar-dasar Konseling Pastoral, (Yogyakarta: ANDI, 2007), 29-39

${ }^{16}$ Howard Clinebell, Tipe-tipe Dasar Pendampingan \& Konseling Pastoral, (Jakarta: BPK Gunung Mulian, 2006), 53-54
} 
menempatkan diri pada tempat konseli, merasakan apa yang dirasakan konseli, dan mengerti dengan pengertian konseli). Ketiga, Acceeptance (sikap menerima konseli apa adanya). Keempat, Listening (kemampuan dan kesediaan mendengar secara profesional). Kelima, Reflective Listening (merefleksikan apa yang sudah didengar). Keenam, Resphonding (Effective Resphonding). ${ }^{17}$

Dengan demikian, seorang konselor yang profesional harus mampu menciptakan suasana yang nayaman bagi konseli serta sanggup menempatkan diri pada diri konseli.

\section{Psikologi}

\section{Etimologis}

Istilah "psikologi" berasal dari kata Yunani, "psyche" yang artinya "jiwa" dan "logos" yang rtinya "ilmu pengetahuan". ${ }^{18} \mathrm{Jadi}$, secara etimologis psikologis artinya ilmu yang mempelajari tentang jiwa, baik mengenai macam-macam gejalanya, prosesnya maupun latar belakangnya. ${ }^{19}$ Istilah psikologi dalam bahasa Inggris "psychology" berasal dari kata "psyche" yang berarti jiwa, nafas, rohani dan semangat. Secara luas, pengetahuan ini menelaah semua gejala kejiwaan atau kerohanian yang terdapat pada makhluk hidup utamanya manusia. ${ }^{20}$ Psikologi konseling adalah sintesis dari berbagai kecenderungan yang berkaitan dalam gerekan bimbingan, kesehatan mental, psikometri, kasus-kasus sosial, dan psikoterapi. ${ }^{21}$ Oleh karena itu, psikologi dapat didefenisikan sebagai suatu studi ilmiah tentang perilaku dan pemikiran organisme.

\section{Konsep Dasar Psikologi}

Psikologi khususnya mengkaji berbagai aspek yang terlibat dalam proses konseling. Aspek-aspek itu meliputi karakteristik, konseling, konselor, konseli dan masalahnya, berbagai kondisi yang menujang dan menghambat konseling, serta metode atau pendekatan-pendekatan dalam konseling. ${ }^{22}$ Secara skematis ruang lingkup psikologi digambarkan sebagai berikut:

17 Yakub B. Susabda, Konseling Pastoral - Pendekatan Konseling Pastoral Berdasarkan Integrasi Teologi dan Psikologi..., 35-52

${ }^{18}$ Abu Ahmadi, Psikologi Sosial, (Jakarta: Rineka Cipta, 2009), 1

${ }^{19}$ Abu Ahmadi, Psikologi Umum, (Jakarta: Rineka Cipta, 2009), 1

${ }^{20}$ Zainal Aqib, Konseling Kesehatan..., 2

${ }^{21}$ Hartono \& Boy Soedarmadji, Psikologi Konseling, (Jakarta: Kencana Prenada Media Group, 2012), 2

\footnotetext{
${ }^{22}$ Hartono \& Boy Soedarmadji, Psikologi Konseling..., 6
} 
Gambar 1: Skema ruang lingkup psikologi konseling

\begin{tabular}{|l|l|l|}
\cline { 2 - 3 } \multicolumn{1}{c|}{} & \multicolumn{2}{c|}{ Psikologi } \\
\cline { 2 - 3 } \multicolumn{1}{c|}{ Mempelajari Psikis dan Perilaku } \\
Klien: Keadaan & Konselor: \\
emosi, & & Menerima klien, \\
penampilan, Pola & & Penampilan, \\
Komunikasi, & Berkomunikasi, \\
Motivasi untuk & & Bahasa verbal dan \\
berubah & & non verbal, \\
& & Berempati, \\
& & Mengarahkan klien \\
\hline
\end{tabular}

Berdasarkan skematis dia atas di dalam proses pastoral konseling, semua aspek tersebut saling terkait, sehingga pendekatan psikologi konseling efektif bagi konselor agar mudah membimbing konseli dalam menyelesaikan permasalahannya.

\section{Fungsi Psikologi}

Psikologi berfungsi agar konselor dapat memperlakukan klien secara tepat sehingga ia dapat memahami diri, mengekspresikan perasaan dan pikiran, menemukan kekuatan diri, mencoba perilaku baru, menguasai ketrampilan baru dan melakukan inovasi diri. Hendra Akhdhiat \& Rosleny Marliani, mendeskripsikan fungsi dari studi psikologi dalam konseling, yakni: Pertama, memahami tigkah laku dengan memberikan perumusan bekerjanya faktor-faktor psikis, yang bersama-sama menentukan perkembangan dan pernyataan tingkah laku. Kedua, menentukan kemungkinan terbesar mengenai tingkahlaku individu pada situasi tertentu. Ketiga, mengembangkan teknik-teknik yang memungkinkan pengendalian tingkahlaku individu dengan mengarahkan perkembangan psikologisnya. ${ }^{23}$

Psikologi secara umum bertujuan untuk mengembangkan penggunaan teoriteori psikologi dalam layanan konseling kepada konseli. Jadi, psikologi berfungsi sebagai pendekatan untuk mempelajari tingkahlaku dan kondisi psikis klien dalam proses pastoral konseling.

\section{Penerapan Psikologi}

Langkah-langkah penerapan psikologi dalam pastoral konseling, sebagai berikut: 1). Menyatakan kepedulian. Maksud dari menyatakan kepedulian atau keprihatinan ialah membentuk hubungan dengan konseli sebagai upaya menjalin

${ }^{23}$ Hendra Akhdhiat \& Rosleny Marliani, Psikologi Hukum, (Bandung, CV. Pustaka Setia, 2011), 9 
kedekatan; 2). Membentuk hubungan. Hal penting untuk Membangun hubungan agar tercipta rasa kepercayaan, keyakinan, keterbukaan dan kejujuran baik konselor maupun konseli; 3). Menentukan tujuan. Konselor harus mentukan arah yang harus dicapai dalam sebuah pelayanan pastoral; 4). Menyelesaikan masalah. Seorang konselor harus bisa menentukan masalah utama dari konseli, kemudian mana yang terlebih dahulu ditangani atau diselesaikan; 5). Menumbuhkan kesadaran. Konselor bertugas menyadarkan atau mengarahkan klien untuk memahami permasalahan yang sedang ia dihadapi, lalu apa yang harus ia perbuat dalam menyelesaikan masalahnya; 6). Merencanakan cara bertindak. Konselor membantu klien untuk merencanakan tindakan atau keputusan untuk menyelesaikan masalahnya; 7). Menilai hasil (evaluasi). Evaluasi merupakan langkah akhir untuk menilai apakah konseling berakhir sesuai tujuan awal. ${ }^{24}$ Oleh karena itu, langkah-langkah psikologi menolong pada konselor Kristen untuk menangani masalah jemaat secara sistimati dan terarah, sehingga pastoral konseling benar-benar menjadi pelayanan yang berhasil.

\section{Psikologi Alkitabiah}

Alkitab mengajarkan bahwa sejak manusia diciptakan memiliki aspek fisik, psikis/intlektual, sosial dan rohani (Kejadian 2:7). Demikian halnya dialami oleh Yesus, Alkitab mencatat: "Dan Yesus makin bertambah besar dan bertambah hikmatNya dan besar-Nya, dan makin dikasihi oleh Allah dan manusia" (Lukas 2:52). Teks ini menjelaskan bahwa Yesus sebagai manusia sejati memiliki aspek fisik, psikis (intlektual), sosial dan spiritual. Atas dasar firman Tuhan tersebut konselor Kristen ketika melayani konseli harus memahami dan mengenal konseli secara utuh, sehingga tidak melihatnya hanya dari satu sisi tetapi secara menyeluruh. Pelayanan pastoral konseling harus menyentuh segala aspek kehidupan manusia baik aspek sipritual, aspek fisik, aspek psikologis dan aspek sosial. Pada bagian ini, peneliti mengemukan pendekatan psikologi Alkitabiah sebagai landasan untuk melayani perempuan yang telah melakukan hubungan seks sebelum menikah, sebagai berikut:

\section{Membangun Hubungan Yang Baik}

Tuhan Yesus ketika melayani perempuan Samaria diawali dengan membangun hubungan atau komunikasi yang baik (Yohanes 4:1-42). Teks tersebut menunjukkan ada tiga langkah yang dilakukan Yesus untuk melayani perempuan Samaria, yakni: 1). Berinteraksi dengan baik. Pada ayat 7, Yesus berkata: Berilah Aku minum." Yesus yang pertama kali memulai komunikasi dengan perempuan Samaria. Yesus menjukkan sikap bersedia membuka diri dan membangun hubungan baik dengan perempaun Samaria. Yesus juga menunjukkan sikap yang ramah dan santun kepada perempuan Samaria dengan mengajukan permintaan agar diberi minum; 2). Menerima apa adanya. Jawaban perempuan Samaria pada ayat 9, mengemukakan bahwa ada konfilik sosial antara orang Yahudi dengan orang Samaria. Orang Yahudi

${ }^{24}$ Zulfan Saam, Psikologi Konseling..., 11-33 
merasa lebih agamawi dibandingkan dengan orang Samaria, sehingga kedua suku bangsa tersebut tidak memiliki relasi yang baik. Namun Yesus yang adalah orang Yahudi asli tidak menunjukkan sikap benci atau jijik, tetapi sebaliknya Yesus menerima perempuan itu tanpa melihat latar belakang serta segala kekurangannya; 3). Mewujudkan keterbukaan diri. Pernyataan Yesus pada ayat 16: "Pergilah, panggilah suamimu datang kesini." Kalimat Yesus tersebut merupakan titik awal perempuan Samaria membuka diri dan menyatakan masalah yang sedang dia alami. Oleh karena itu, seorang konselor Kristen harus bisa menjukkan sikap yang baik kepada konseli misalnya rasa empati, ramah dan menerima konseli apa adanya.

\section{Menunjukkan Sikap Yang Baik}

Injil Matius 9: 36 tertulis: "Melihat orang banyak itu, tergeraklah hati Yesus oleh belas kasihan kepada mereka, karena mereka lelah dan terlantar seperti domba yang tidak bergembala."Sikap yang ditunjukkan oleh Tuhan Yesus ialah sikap hati yang penuh belaskasihan dan berempati kepada mereka yang membutuhan pertolongan. Kemudian kitab Ibrani 4: 15: "Sebab Imam Besar yang kita punya, bukanlah imam besar yang tidak dapat turut merasakan kelemahan-kelemahan kita, sebaliknya sama dengan kita, Ia telah dicobai, hanya tidak berbuat dosa." Tuhan Yesus menempatkan diri seperti orang percaya sehingga Dia dapat merasakan semua kelemahan, kesusahan, penderitaan dan segala persoalan pengikut-Nya. Kemudian Yesus mengajarkan bahwa: "Inilah perintah-Ku, yaitu supaya kamu saling menasihi, seperti Aku mengasihi kamu” (Yohanes 15:12). Seorang konselor Kristen harus bisa menunjukkan sikap rasa empati, perhatian dan kepedulian yang memungkinkan konseli lebih terbuka sehingga tujuan akhir dari pelayanan pastoral konseling dapat tercapai.

\section{Membimbing Konseli}

Sebagaimana Tuahan Yesus perintahkan kepada Petrus dalam Yohenes 21:17: "Gembalakanlah domba-domba-Ku." Istilah gembalakanlah berarti merawat, memberi makan. Raja Daud berkata dalam Mazmur 23:1-2: "Tuhan adalah gembalaku, takkan kekurangan aku, Ia membaringkan aku di padang yang berumput hijau, Ia membimbing aku di air yang tenang." Dari kedua teks firman Tuhan tersebut menjelaskan tentang Tugas konselor sebagai pemberi makan secara rohani, menuntun, membimbing konseli untuk menemukan jalan keluar atau solusi dari persoalannya sehingga mengalami kelegaan.

Tugas konselor menyadarkan konseli bahwa dia diciptakan segambar dan serupa dengan Allah (Kejadian 1:26). Konseli harus memahami bahwa dia seorang yang berharga dan mulia di mata Tuhan (Yesaya 43:4). Disisi lain konseli juga harus memahami dia adalah munusia berdosa (Roma 3:23), maka konselor menuntun konseli untuk menerima keselamatan di dalam Yesus Kristus (Kisah Para Rasul 4:12). Kemudian konselor menuntun konseli supaya bertanggung jawab untuk 
pertumbuhan iman di dalam Tuhan melalui persekutuan, pembacaan firman Tuhan dan berdoa (Ibrani 10:25, 1 Timotius 3:16, Roma 12:12).

\section{Proklamasi Kristus}

Keberadaan perempuan yang telah melakukan hubungan seks sebelum menikah harus dituntun untun menerima Tuhan Yesus secara pribadi. Konselor menuntun konseli untuk mengakui segala dosa di hadapan Tuhan (1 Yohanes 1:8-9). Kemudian membawa konseli untuk memahami arti keselamatan di dalam Yesus Kristus dan menuntun dia menerima keselamatan itu. Rasul Paulus menuliskan dalam Efesus 2:8 "Sebab karena kasih karunia kamu diselamatkan oleh iman, itu bukan hasil usahamu, tetapi pemberian Allah." Penulis kitab Kisah Para Rasul menegaskan bahwa: "Dan keselamatan tidak ada di dalam siapa pun juga selain di dalam Dia, sebab di bawah kolong langit ini tidak ada nama lain yang diberikan kepada manusia yang olehnya kita dapat diselamatkan" (Kisah Para rasul 4:12).

Pendapat Charles Stanley terkait pengampunan bahwa: "Pengampunan merupakan suatu cara untuk membawa damai sejahtera di dalam hati. Jika anda tidak mengampuni, anda akan dihabiskan secara terus menerus oleh ingatan-ingatan perlakuan tersebut. Ingatan ini akan melemahkan emosi anda dan perasaan anda akan rusak. Pengampunan merupakan hal yang mutlak jika anda ingin sehat." 25 Mengampuni satu tindakan yang harus dilakukan setiap orang yang tersakiti, terluka, kecewa dan menyimpan kepahitan dengan orang lain, agar hatinya dipenuhi damai sejahtera dan sukucita. Oleh sebab itu, konselor harus menyampaikan kebenaran kepada perempuan yang telah melakukan hubungan seks sebelum menikah agar mengampuni semua orang yang menyakitinya secara khusus laki-laki yang telah menjadi suaminya.

\section{Pemulihan Seutuhnya}

Alkitab dengan gablang menjelaskan bahwa seseorang harus meninggalkan kebiasan-kebiasaan buruk seperti pikiran negatif, kata-kata kotor, perbuatan daging dan semua tingkah laku yang tidak berkenan kepada Tuhan (Roma 12:2; Galatia 5:16-17; Filipi 2:5). Rasul Paulus mengungkapan: "Jadi siapa yang ada di dalam Kristus, ia adalah ciptaan baru yang lama sudah berlalu, sesungguhnya yang baru sudah datang" (1 Korintus 5:17).

Konselor Kristen menuntun konseli supaya ia sadar akan dosa-dosanya, mengakuinya dihadapan Allah, berkomitmen untuk meninggalkan dosa-dosa dimasa lalu (pertobatan) dan menerima Yesus Kristus sebagai Tuhan dan Juruselamat pribadinya (lahir baru). Setelah mengalami hidup baru di dalam Krsitus konseli berkewajiban membangun imannya agar bertumbuh menuju kesempurnaan seperti Kristus (Matius 5:48, Efesus 4:15).

\footnotetext{
${ }^{25}$ Charles Stanley, Menyembuhkan Hati Yang Luka, (Yogyakarta ANDI, 1994), 92-93
} 
Salah satu fungsi pelayanan pastoral konseling ialah supaya konseli mengalami pemulihan yang seutuhnya di dalam Yesus Kristus. Tuhan Yesus berkata: "Marilah kepada-Ku, semua yang letih lesu dan berbeban berat, Aku akan memberi kelegaan kepadamu" (Matius 11:28).

\section{$\underline{\text { Hakikat Perempuan Menurut Alkitab }}$}

\section{Asal usul perempuan}

Kata perempuan dalam bahasa Ibrani, yaitu: isysya dapat diartikan: ibu, istri. ${ }^{26}$ Kata ini pertama sekali digunakan pada Kejadian 2:23. Istilah "perempuan" dalam Perjanjian Baru dari kata Yunani: gune artinya: perempuan, istri, ibu, janda, pengantin, tunangan, perempuan yang tunangan. ${ }^{27}$ Tuhan merancang dan mengambil bahan baku untuk menciptakan perempuan dari tulang rusuk laki-laki (Kejadian 2:22) dan dia dinamai perempuan sebab ia diambil dari laki-laki (Kejadian 2:23). Senada dengan itu, Charles C. Ryrie menuliskan, pertama-tama Allah mengambil tulang rusuk Adam kemudian membentuknya dalam rupa wanita. Allah membentuk Hawa setelah mengambil rusuk Adam. ${ }^{28}$ Membentuk berati menata struktur penting yang membutuhkan upaya yang konstruktif. Maka, Perempuan (Hawa) diciptakan langsung oleh Allah dari unsur laki-laki

\section{Perempuan Adalah Ciptaan Tuhan Yang Mulia}

Alkitab mengatakan bahwa Allah menciptakan perempuan dan laki-laki menurut gambar dan rupa Allah. Kejadian 1:27 "Maka Allah menciptakan manusia itu menurut gambar-Nya, menurut gambar Allah diciptakan-Nya dia; laki-laki dan perempuan diciptakan-Nya mereka". Kata "gambar" dan "rupa" dalam bahasa aslinya (tselem) artinya: gambar, ilusi, kemiripan, model, bentuk. ${ }^{29}$ Maksud dari ungkapan menurut gambar dan rupa Allah dalam ayat ini tidak dalam arti bahwa manusia itu sama hakikat dengan Sang Pencipta. Ungkapan itu lebih berarti bahwa Allah menciptakan manusia sebagai makluk mulia, kudus, dan berakal budi, sehingga manusia bisa berkomunikasi dengan Allah, serta layak menerima mandat dari Allah untuk menjadi pemimpin bagi segala makluk (Kejadian 1:28-30). Manusia diciptakan seturut dengan gambar Allah menjelaskan mengenai natur keduanya. Allah menciptakan manusia sebagai keberadaan yang unik. Alkitab menyajikan manusia sebagai gambar Allah dimaknai sebagai makhluk bermoral, memiliki jiwa dan kekal

\footnotetext{
${ }^{26}$ John Joseph Owens, Analytical Key To The Old Testament, (Michigan Grand Rapids: Baker Book House, 1999), 10

${ }^{27}$ Hasan Sutanto, Perjanjian Baru Interlinier dan Konkordansi Perjanjian Baru II, (Jakarta: LAI, 2004), 177-180

${ }^{28}$ Charles C. Ryrie, Teologi Dasar I, (Yogyakarta: Andi, 2018), hlm. 277

${ }^{29}$ James Strong, The Exhaustive Concordance,..., 99
} 
(Kejadian 2:7). ${ }^{30}$ Dengan demikian, perempuan diciptakan Tuhan sebagai makhluk yang memiliki sifat yang unik, berakhlak, berhati nurani dan memiliki hidup yang kekal.

\section{Perempuan Adalah Dikasihi Allah}

Allah mencintai para perempuan. Peremuan merupakan ciptaanNya yang unik. Setiap wanita diciptakan Tuhan istimewa. Tuhan peduli kepada perempuan sebagaimana Dia peduli kepada laki-laki. ${ }^{31}$ Tuhan Yesus telah menunjukkan bahwa Dia mengasihi perempuan. Yesus menyembuhkan ibu mertua Petrus (Matius 8:5-13). Yesus menyembuhkan perempuan yang sakit pendarahan (Markus 5: 25-34). Yesus memberitakan kabar baik kepada perempuan Samaria (Yohanes 4:1-26). Kemudian Maria dan beberapa perempuan lain mengiring Yesus dalam pelayanan-Nya (Luk 24:10). Yesus juga mengatakan bahwa barang siapa menceraikan istrinya dan menikah dengan orang lain, berbuat zina terhadap istrinya (Markus 10:11,12). Maka, Yesus menolak ajaran yang populer dari para rabi yang memperbolehkan suami menceraikan istri atas dasar apapun (Matius 19:3,9). Pernyataan Yesus tersebut menempatkan suami dan istri di bawah kewajiban moral yang sama, Yesus mengangkat status dan martabat perempuan. Bukti kasih Yesus bagi perempuan, Dia rela menderita dan mati di kayu salib untuk menebus dosa semua manusia termasuk di dalamnya dosa para perempuan.

\section{Perempuan Adalah Sederajat Dengan Laki-Laki}

Tuhan menciptakan pria dan perempuan serupa menurut gambar-Nya (Kejadian 1:27). Allah menciptakan wanita bukanlah dari debu tanah melainkan dia diambil dari tulang rusuk seorang pria (Kejadian 2:22) Perempuan diciptakan bukan untuk ditaklukkan ataupun ditinggikan. Itu berarti wanita tidak lebih rendah daripada lakilaki di hadapan Tuhan. Pria dan wanita memiliki kedudukan dan otoritas yang sama di hadapan-Nya. Dalam pandangan Tuhan Yesus bahwa wanita bukanlah warga kelas dua yang dikesampingkan kepentingannya. Wanita layak mendapat tempat dan kesempatan yang setara dengan pria, juga dalam hal menerima anugerah keselamatan dari Allah. Walaupun Alkitab menyebutkan perbedaan peranan di antara pria dan wanita, yang jelas tak ada perbedaan hak untuk menerima kasih karunia Allah (Galatia 3:28-29).

\section{Peranan Perempuan}

\section{a. Peranan Perempuan Bagi Suami}

Dalam Kejadian 2:18 disebutkan bahwa peranan perempuan bagi laki-laki ialah sebagai penolong. Istilah "penolong" dalam bahasa Ibrani dari kata (ezer)

\footnotetext{
${ }^{30}$ Paul Enns, The Moody Handbook Of Theology I, (Malang: Literatur SAAT, 2018), 375

${ }^{31}$ Edwin Lois, Wanita Unik, (Jakarta: Yayasan Pekabaran Injil "Imanuel”), 26
} 
diterjemahkan "penolong". ${ }^{32}$ Kata "ezer" dalam tatanan bahasa Ibrani memiliki konotasi yang kuat, bukan penolong yang lemah atau rendah, itu sebabnya kata "ezer" seringkali dipakai atribut Allah sebagai penolong umatNya. ${ }^{33}$ Wanita diciptakan untuk menjadi rekan yang mengasihi dan menolong laki-laki. Selaku rekan ia harus bersama-sama menanggung tanggung-jawab laki-laki dan bekerja sama dengannya dalam memenuhi maksud Allah bagi kehidupan laki-laki dan keluarga mereka.

\section{b. Peranan Perempuan Bagi Anak}

Amsal 31: 27a, "Ia mengawasi segala perbuatan rumah tangganya". Salah satu peranan perempuan (ibu) bagi anak ialah sebagai pengasuh dan mengawasi segala perilaku mereka. Anak membutuhkan kehadiran ibunya agar dia mendapat perlindungan dan rasa aman. Kemudian perempuan tidak saja sebagai pengasuh bagi anak sekaligus sebagai pengajar yang baik. ${ }^{34}$ Amsal 6:20 "Hai anakku, peliharalah perintah ayahmu, dan janganlah menyia-nyiakan ajaran ibumu." Seorang perempuan memainkan peran utama dalam mengajar anak-anaknya tentang ketrampilan, ilmu pengetahuan, etika moral, tata cara kehidupan, budaya dan terlebih hal-hal rohani.

\section{c. Peranan Perempuan Bagi Gereja}

Alkitab mencatat beberapa tokoh perempauan yang diberi tanggung jawab sebagai nabiah, pemimpin, hakim dan juga sebagai teladan dalam hal perbuatan baik. Hakim-hakim 20:20-21, mengisahkan seorang perempuan yang hebat bernama Debora. Dia adalah seorang nabiah dan sekaligus seorang hakim bagi bangsa Israel. II Raja-raja 4:8-10, perempuan Sunem seorang yang kaya raya memiliki karunia memberi dan bermurahati. Dia memiliki peran untuk memelihara Elisa sebagai hamba Allah agar pekerjaan Tuhan berjalan dengan baik.

Oleh karena itu, Tuhan memberikan kemampuan dan tanggung-jawab khusus bagi para perempuan menjadi pemimpin di dalam dunia serta pemimpin dalam hal rohani. Para perempuan menunjukkan keteladanan dalam membangun tubuh Kristus dengan cara bersekutu, berdoa, memberitakan Injil, berbelaskasihan dan berbagi kepada yang lain.

\section{$\underline{\text { Psikologi Perempuan }}$}

\section{Remaja (17-21 tahun)}

Pada masa ini, remaja perempuan mengalami badai dan topan dalam kehidupan perasaan dan emosinya. keadaan semacam ini sering disebut strom and stress.

\footnotetext{
${ }^{32}$ Jay P. Green, The Intelinier Bible Hebrew/English, (Michigan Grand Rapids: Baker Book House, 1981), 5

${ }^{33}$ Andik Wijaya, Sexual Holiness Vol. 6, (Surabaya: Kenza Publising House, 2014), 13-14

${ }^{34}$ Gene A. Getz, Citra Wanita Kristen, (Jakarta: BPK Gunung Mulia, 1994), 82-83
} 
Remaja perempuan seringkali kelihatan sangat bergairah dalam bekerja tiba-tiba berganti lesu. Kegembiraan yang meledak bertukar rasa sedih yang sangat, rasa percaya diri berganti dengan rasa ragu-ragu yang berlebihan, termasuk ketidak tentuan dalam menentukan cita-cita. ${ }^{35}$

Fase ini sudah mulai menenemukan nilai-nilai hidup baru, sehingga semakin jelaslah pemahaman tentang keadaan diri sendiri. Ia mulai bersikap kritis terhadap kritis terhadap obyek-obyek di luar dirinya dan ia mampu mengambil sintesis antara dunia luar dan dunia internal. Secara obyektif dan aktif ia melibatkan diri dengan kegiatan dunia luar, sambil mencoba mendidik dirinya sendiri. Pada fase perkembangan ini dibangun dasar-dasar yang definitif (esensial) bagi pembentukan kepribadiannya. Pada fase ini perempuan cenderung banyak menuntut, sensitif mudah menggugah harga diri berlebihan. ${ }^{36}$ Masa ini seringkali disebut sebagai masa krisis bagi remaja perempuan oleh karena belum memiliki kematangan dalam berpikir yang akan mempengaruhi seluruh aspek kehidupannya seperti perasaan, cinta, emosi, keputusan, sikap dan perilaku.

\section{Dewasa Awal (22-40)}

Dewasa awal adalah masa peralihan dari masa remaja. Masa remaja yang ditandai dengan pencarian identitas diri, sedangkan masa dewasa awal identitas diri ditemukan dengan sendirinya. ${ }^{37}$ Perempuan dewasa awal adalah masa peralihan dari ketergantungan kemasa mandiri, baik dari segi ekonomi, kebebasan menentukan diri sendiri dan pandangan tentang masa depan sudah lebih realistis. Segi emosional, pada masa dewasa awal adalah masa dimana motivasi untuk meraih sesuatu sangat besar yang didukung oleh kekuatan fisik yang prima. ${ }^{38}$ Sebut perempuan dewasa awal karena sudah bisa bertanggung jawab terhadap diri sendiri, bertanggung jawab atas nasib sendiri dan atas pembentukan diri sendiri. Bertanggung jawab itu bisa diartikan telah memahami arti dari pada norma-norma susila dan nilai-nilai etis tertentu, berusaha hidup atas nila-nilai yang dipahami dan berusaha mencapai nilai-nila yang sudah dikenalnya itu.

\section{$\underline{\text { Kejatuhan Manusia Di Dalam Dosa }}$}

\section{Pengertian Dosa}

Dalam Perjanjian Lama istilah dosa sering menggunakan kata (Khattat) yang berarti: dosa. ${ }^{39}$ Kata ini muncul ratusan kali dalam Perjanjian Lama (522 kali). Salah satu contoh dalam Kejadian 4:7 kata "Dosa" dalam ayat tersebut berasal dari bahasa Ibrani "Khattat". Kata "Khattat" mengungkapkan tentang pikiran yang tidak

\footnotetext{
${ }^{35}$ Giri Wiarto, Psikologi Perkembangan Manusia, (Yokyakarta: Psikosain, 2015), 83

${ }^{36}$ Kartini Kartono, Psikologi Wanita, (Bandung: Alumni, 1977), 76-77

${ }^{37}$ Giri Wiarto, Psikologi Perkembangan..., 116-117

${ }^{38}$ Kartini Kartono, Psikologi Wanita..., 175-176

${ }^{39}$ Jay P. Green, The Intelinier Bible..., 9
} 
mengenai sasaran, membuat kesalahan, luput atau gagal. ${ }^{40}$ Dalam pengertian ini, dosa mengacu kepada arti bahwa manusia tidak kena sasaran, tidak sampai atau menyimpang dari tujuan dan maksud Allah.

Kata "dosa" dalam bahasa Yunani yang sering digunakan ialah (hamartia) berarti: dosa. ${ }^{41}$ Istilah hamartia juga bisa diartikan yaitu meleset dari sasaran, meninggalkan jalan kebenaran". ${ }^{42}$ Dosa ialah kegagalan untuk selaras dengan standar Allah. Dosa dapat diartikan semua yang tidak bisa diterima oleh Allah. ${ }^{43}$ Arti yang lain dari dosa ialah pelanggaran hukum (II Korintus 6:14), atau kejahatan moral (1 Yohanens 3:12).

\section{Awal Mula Dosa}

Peristiwa yang mengenaskan di Taman Eden menjadi titik awal manusia jatuk ke dalam dosa (Kejadian 3:6-7). Kegagalan manusia menaati perintah Tuhan menjadikan dosa masuk ke dalam dunia dan semua keturunannya ialah berdosa. Roma 5:12, tertulis: "Sebab itu, sama seperti dosa telah masuk ke dalam dunia oleh satu orang, dan oleh dosa itu juga maut, demikianlah maut itu telah menjalar kepada semua orang, karena semua orang telah berbuat dosa". Kebenaran ini menjelaskan bahwa dosa bersal dari Adam sebagai manusia yang pertama.

Menurut Henry C. Thiessen, bahwa Alkitab menganjarkan oleh karena satu perbuatan dosa dari satu orang, dosa telah memasuki dunia, dan bersamaan dengan itu semua akibat dosa yang terasa dimana-mana (Roma 5:12; I Korintus 15:21-22) dan satu orang ini adalah Adam. ${ }^{44}$ Oleh karena itu, Adam masuk dalam sejarah masuknya dosa ke dalam dunia serta dosa tersebut telah menjalar kepada semua manusia.

\section{Sifat Dosa}

Dalam Kejadian 4:7, Iblis diibaratkan sebagai seorang musuh yang senantiasa mengintip di depan pintu hati manusia. Itulah sebabnya Rasul Petrus mengingatkan supaya manusia tetap berjaga-jaga, sebab Iblis bagaikan singa yang mengaum dan senantiasa mencari mangsa (1 Petrus 5: 8). Iblis selalu menyembunyikan diri, tidak mau dikenal dalam sifatnya yang sesungguhnya dan senantiasa menutupi maksudnya yang sebenarnya. Sifat dosa selalu menyembunyikan diri di belakang perbuatanperbuatan yang tampak baik. Kemudian sifat dosa yang lain ialah turun temurun. Pengajaran ini diperkuat oleh pernyataan raja Daud di dalam Mazmur 51:7, "Sesungguhnya, dalam kesalahan aku diperanakkan, dalam dosa aku dikandung ibuku". Itu berarti semua manusia yang dilahirkan ke dalam dunia ini memiliki sifat

\footnotetext{
${ }^{40}$ Charles C. Ryrie, Teologia Dasar..., 305-306

${ }^{41}$ Hasan Sutanto, Perjanjian Baru Interlinier..., 52

${ }^{42}$ Paul Enns, The Moody Handbook Of Theology II, (Malang: Literatur SAAT, 2008), 383

${ }^{43}$ W.R.F. Browning, Kamus Alkitab, (Jakarta: BPK Gunung Mulia, 2008), 84-85

${ }^{44}$ Henry C. Thiessen, Teologi Sistimatika, (Malang: Gandum Mas, 2008), 276
} 
yang sama yakni mewarisi natur dosa. ${ }^{45}$ Manusia juga orang berdosa oleh karena pelanggaran-pelanggaran yang diperbuat secara pribadi (1 Yohanes 1: 8).

\section{Akibat Dosa}

Alkitab secara keseluruhan menjelaskan beberapa akibat dosa yang dialamai oleh manusia sebagai berikut:

\section{Terpisah Dari Allah}

Pada waktu manusia jatuh ke dalam dosa secara otomatis manusia terpisah dengan Allah. Dosa mengakibatkan maut dan pemisahan roh manusia dari Allah sebagai sumber kehidupan. ${ }^{46}$ Pemahaman ini dibenarkan di dalam kitab Yesaya 59:2, "Tetapi yang merupakan pemisah antara kamu dan Allahmu ialah segala kejahatanmu, dan yang membuat Dia menyembunyikan diri terhadap kamu, sehingga Ia tidak mendengar, ialah segala dosamu".

\section{Mengalami Kematian}

Kematian yang dialami manusia akibat dosa adalah meliputi: Pertama, kematian fisik. Kematian fisik dapat disebut kematian sementara. Kematian fisik akan menghampiri setiap orang pada saat jiwa dan raganya terpisah. Alkitab menyaksikan bahwa kematian fisik sebagai bagian dari hukuman atas dosa (Bilangan 16:29; Mazmur 90:7-11; Yohanes 8:44; Roma 6:9). Kedua, kematian rohani. Kematian rohani merupakan terpisahnya jiwa dari Allah (Kejadian 2:17; Roma 5:21; Efesus 2:1). Ketiga, kematian kekal. Kematian kekal ialah terpisahnya jiwa dari Allah secara kekal atau penghukuman kekal di dalam neraka (Matius 10:28; II Tesalonika 1:9; Ibrani 10:31). ${ }^{47} \mathrm{Jadi}$, dosa telah berkuasa untuk menjadikan manusia mengalami kematian secara fisik, rohani dan kematian kekal.

\section{$\underline{\text { Seks Menurut Alkitab }}$}

\section{Pengertian Seks}

Istilah "seks" berasal dari bahasa Latin "sexus" kemudian diturunkan menjadi bahasa Perancis Kuno "sexe". Istilah ini diterjemahkan dalam bahasa Inggris sebagai kata benda "noun", kata sifat "adjective", maupun kata kerja transitif "verb of transitive" 48 Kamus Besar Bahasa Indonesia (SBBI) kata "seks" diartikan: jenis kelamin, hal yang berhubungan dengan alat kelamin seperti sanggama, dan berahi. ${ }^{49}$

${ }^{45}$ John R.W. Stott, Kedaulatan Dan Karya Kristus, (Jakarta: Yayasan Komunikasi Bina Kasih, 2008), 80-81

${ }^{46}$ John R.W. Stott, Kedaulatan Dan Karya Kristus..., 95

${ }^{47}$ G. J. Baan, Tulip: Lima Pokok Calvinisme, (Surabaya: Momentum, 2014), 17-18

${ }^{48}$ Jarot Wijarko, Cinta Sex Pacaran, (Jakarta: Suara Pemulihan, 2012), 24

${ }^{49}$ A. Moeliono, Kamus Besar Bahasa Indonesia, (Jakarta: Balai Pustaka, 1988), 417 
Seks adalah perbedaan badani atau biologis perempuan dan laki-laki yang sering disebut jenis kelamin.

\section{Satu Daging}

\section{Hakikat Seks Menurut Alkitab}

Kata "satu" dalam bahasa Ibrani menggunakan kata (ehad) artinya satu. ${ }^{50}$ Memiliki pengertian bahwa dua orang menjadi satu atau satu ditambah satu menjadi satu kesatuan yang tidak dapat dipisahkan (Kejadian 2:24 dan Matius 19:6). Kata "daging" dalam bahasa Ibrani dari kata (bazar) artinya: tubuh, daging. ${ }^{51}$ Kata bazar bisa diartikan pedenda atau organ reproduksi. ${ }^{52}$ Kata "bazar" merupakan unsur utama tubuh atau badan manusia (Kejadian 40:19). Apabila kedua kata tersebut digabungkan, maka dapat disimpulkan istilah "satu daging" berbicara mengenai seksualitas manusia antara seorang laki-laki dan seorang perempuan. Kata tersebut juga memberi makna bahwa Tuhan mempersatukan seorang laki-laki dan perempuan agar mereka masuk dalam persekutuan rumah tangga yang baik dan setia. Penjelasan satu daging tidak memberi ruang terhadap perzinahan, poligami, seks sejenis dan perceraian (Matius 19:6).

\section{Bersetubuh}

Istilah "bersetubuh" pertama sekali dipakai dalam Kejadian 4:1. Kata "bersetubuh" dalam bahasa Ibrani memakai kata (yada) diterjemahkan dalam bahasa Inggris "know" dapat diartikan mengenal, mengerti, memperhatikan. ${ }^{53}$ Kata "yada" juga memiliki arti relasi, hubungan, keintiman. Kata "bersetubuh" dalam bahasa Inggris ialah "intercourse" yang berarti hubungan kelamin, seksual, bersetubuh, tidur bersama, mengauli, bersenggama dan persetubuhan. ${ }^{54}$ Kata tersebut apabila dikaitkan dengan seks dapat diterjemahkan sebagai tindakan seksual yang terjadi antara Adam dan Hawa sebagai pasangan suami istri.

\section{Ciri Seks Menurut Alkitab}

\section{Seks Adalah Inisiatif Allah}

Alkitab menyaksikan bahwa Allah yang merancang adanya seks dalam kehidupan manusia. Allah dengan sengaja menciptakan laki-laki dan perempuan dengan orientasi seksnya masing-masing (Kejadian 1:27). Sejak semula telah ditetapkannya ada dua jenis kelamin dan itu sungguh amat baik (Kejadian 1:31).

50 James Strong, The Exhaustive Concordance Of The Bible, (Peabody, Massachusetts: Hedrickson Publisers), 24

51 Jay P. Green, The Interlinier Hebrew-Aramic Old Testament, (Peabody, Massachusetts: Hedrickson Publisers, 1991), 6

${ }_{52}$ Andik Wijaya, Sexual Holiness Vol. 5, (Surabaya: Kenza Publising House, 2014), 47

${ }^{53}$ Jay P. Green, Interlinier Hebrew-Aramic Old Testament..., 9

${ }^{54}$ Andik Wijaya, Sexual Holiness Vol. 3, (Surabaya: Kenza Publising House, 2014), 35 
Allah melengkapai manusia dengan organ seks dan dorongan sexual. ${ }^{55}$ Pada prinsipnya Allah berkenan dan merestui adanya hubungan seks. Seks adalah anugrah Allah yang harus dinikmati oleh setiap orang yang telah berhak menikmatinya.

\section{Seks Adalah Baik}

Seks sudah ada sebelum manusia jatuh ke dalam dosa. Kejadian 2:25, "Mereka keduanya telanjang, manusia dan istrinya itu, tetapi mereka tidak merasa malu". Teks ini membenarkan bahwa seks bukan sesuatu yang kotor dan menjijikkan oleh karena manusia itu telanjang tapi mereka tidak merasa malu. Lebih tegas dituliskan oleh Jarot Wijanarko bahwa:

Setelah Tuhan menciptakan manusia, sebagaimana manusia itu ada, termasuk organ dan hormon seksualnya, dorongan seksualnya dan kemampuan untuk berkembangbiak, maka Tuhan berfirman, bahwa semua itu baik. Seks adalah kudus, bahkan itu perintah Tuhan. Seks bukan sesuatu yang masuk ke dalam manusia setelah manusia jatuh dalam dosa, bukan, seks yang ada dalam diri manusia adalah karya Tuhan. ${ }^{56}$

Seks adalah hal yang terindah, mempesona dan menyenangkan bagi setiap orang yang telah berhak menikmatinya.

\section{$\underline{\text { Seks Sebelum Menikah }}$}

\section{Pengertian Seks Sebelum Menikah}

Hubungan seks sebelum menikah sering disebut hubungan seksual pranikah (premarital sexual intercourse) atau hubungan seksual tanpa menikah. Hubungan seksual pranikah adalah hubungan seksual yang dilakukan oleh pasangan kekasih laki-laki dan perempuan sebelum akhirnya mereka melangsungkan pernikahan. Sementara hubungan seksual tanpa menikah umumnya menunjuk pada hubungan seksual yang dilakukan pasangan laki-laki dan perempuan yang menjalani hidup bersama tetapi tanpa pernikahan. ${ }^{57}$ Oleh karena itu, seks sebelum menikah ialah merupakan suatu hubungan seksual yang dilakukan oleh pasangan laki-laki dan perempuan yang tanpa atau belum ada ikatan pernikahan.

${ }^{55}$ Mary Ann Mayo, Pendidikan Seks Dari Orangtua Kepada Anak, (Bandung: Yayasan Kalam Hidup, 1986), 54

${ }_{56}^{57}$ Jarot Wijarko, Cinta Sex..., 26

${ }^{57}$ Herbert J. Miles, Seks Sebelum Pernikahan, (Jakarta: BPK Gunung Mulia, 1983), 93-96 


\section{Seks Sebelum Menikah Menurut Alkitab}

\section{Percabulan}

Dituliskan dalam Perjanjian Lama bahwa seks yang dilakukan diluar pernikahn ditentang secara keras (Im. 19:29; Ul. 23:18-19; Yer. 5:8; Ams. 2:7). Perjanjian Lama menuliskan bahwa seandainya seorang perempuan dinikahi oleh seorang laki-laki lalu diketahui tidak perawan lagi, maka perempuan itu harus dirajam (Ul. 22:21). Demikian dalam Perjanjian Baru menolak secara keras setiap bentuk percabulan (porneia) dan melihatnya sebagai hal yang bertentangan dengan kebenaran Kerajaan Allah. Kitab Injil mencatat bahwa Kristus memasukkan percabulan bersama perceraian ke dalam daftar kejahatan yang berasal dari hati dan Dia pun menajiskannya (Mat 15:19-20; Mrk 7:21-23).

Surat-surat Paulus berkali-kali mengecam tindakan seksual amoral. Paulus tampaknya lebih sering berbicara tentang percabulan (porneia) dari pada tentang perceraian atau perselingkuhan (moikheia). Dalam 1 Korintus 7:1-2, Paulus menilai bahwa sebenarnya baik kalau seorang laki-laki tidak beristri. Namun, karena bahaya porneia, maka setiap laki-laki sebaiknya memiliki istri dan setiap perempuan memiliki suami. Paulus tampaknya mau menegaskan bahwa hubungan seksual hanya boleh terjadi di dalam pernikahan.

\section{Perzinahan}

Penulis Kitab Ibrani mengatakan, "Hendaklah kamu semua penuh hormat terhadap perkawinan dan janganlah kamu mencemarkan tempat tidur, sebab orangorang sundal dan pezinah akan dihakimi Allah" (Ibrani 13:4). Hubungan seksual yang terjadi sebelum pernikahan disebut "percabulan" (Kisah Para Rasul 15:20; 1 Korintus 6:18) dan hubungan seksual yang dilakukan di luar hubungan pernikahan disebut "perzinahan" (Keluaran 20:14; Matius 19:9). Baik percabulan maupun perzinahan, keduanya sangat dilarang di dalam Alkitab. Dalam istilah Alkitab imoralitas seksual adalah semua hubungan seks di luar pernikahan termasuk sebelum menikah. Dengan demikian, Alkitab memandang dosa seksual sebagai hal yang serius. Yesus memperingatkan bahwa akibat dari dosa seksual ini dapat melemparkan seseorang ke dalam neraka (Matius 5:27-30).

\section{Faktor Seks Sebelum Menikah}

\section{Biologis}

Masa remaja (Adolescence) sebagai periode transisi perkembangan antara masa kanak-kanak dengan masa dewasa, yang melibatkan perubahan-perubahan biologis, kognitif, dan sosio-emosional. Aspek perubahan fisik yang dialami remaja berhubungan dengan produksi hormon seksual dalam tubuh yang mengakibatkan 
timbulnya dorongan emosi dan seksual. ${ }^{58}$ Hal ini menjadi titik rawan karena remaja mempunyai sifat selalu ingin tahu dan mempunyai kecenderungan mencoba sesuatu yang baru. Masa pubertas bagi remaja merupakan masa krisis untuk mencari jati diri yang sesunggunya. Berusaha mengaktualisasikan diri pada lingkungannya termasuk gairah seksual terhadap lawan jenisnya, sehingga perilaku seksual sebelum menikah kebanyakan terjadi diusia remaja.

\section{Pacaran}

Pacaran merupakan proses perkenalan antara dua insan manusia yang biasanya berada dalam rangkaian tahap pencarian kecocokan menuju kehidupan berkeluarga yang dikenal dengan pernikahan. Berpacaran adalah interaksi heteroseksual yang didasari oleh rasa cinta, kasih dan sayang untuk menjalin suatu hubungan yang lebih dekat. ${ }^{59}$ Pada esensinya pacaran ialah untuk saling mengenal lebih jauh menuju pernikahan atau untuk mencari pasangan hidup. Pacaran sering disalah artikan oleh para generasi muda sehingga timbul perbuatan yang menyimpang.

Bagi yang berpacaran sering berasumsi bahwa cinta sama dengan seks. Suatu pengertian yang menyesatkan dan menjerumuskan. Tidaklah heran jika masa pacaran sudah bersikap negatif seperti ciuman, pelukan, meraba, dan petting yang mendorong melakukan seks sebelum menikah. Oleh karena itu, dapat dipastikan masa pacaran salah satu penyebab utama terjadinya hubungan seks sebelum menikah.

\section{Kurangnya Pendidikan Seks}

Bagi sebagian orang seks memang masih dianggap tabu dan hanya konsumsi orang dewasa. Sehingga berbicara mengenai seks harus secara tersembunyi. Semestinya sedini mungkin pendidikan seks harus disampaikan khususnya kepada para remaja perempuan. Pada usia tertentu remaja perempuan mengalami perubahan organ-organ seks, baik primer maupun sekunder. Masa ini dikenal sebagai masa pubertas. Masa perubahan fisik pada remaja perempuan seringkali diabaikan oleh orang tua, guru, bahkan para hamba Tuhan sehingga para remaja perempuan tindak mendapat pengetahuna seks yang baik. Akibat dari kurangnya pengetahuan tentang seks, seringkali perilaku seks menjadi salah arah. Oleh sebab itu, dapat dipastikan bahwa kurangnya pendidikan seks menyebabkan perempuan melakukan hubungan seks sebelum menikah.

\section{Orangtua}

Penyebab lain dari perilaku seks sebelum menikah ialah latar belakang keluarga. Orangtua merupakan figur utama yang harus diteladani oleh setiap anak. Segala segi perilaku orang tua mulai dari perkataan, kebiasaan, perbuatan akan diamati dan ditiru oleh anak. Orangtua yang relasinya tidak harmonis berdampak

\footnotetext{
${ }^{58}$ Giri Wiarto, Psikologi Perkembangan Manusia, (Yogyakarta: Psikosain, 2015), 80-84

59 Jarot Wijarko, Cinta Sex Pacaran..., 73
} 
pada kurangnya perhatian orang tua kepada anak. Salah satu contoh anak dari korban brocan home tidak mendapat perhatian yang seimbang dari kedua orang tuanya. Keadaan ini mempengaruhi prilaku negatif anak. Kemudian pendidikan yang salah dalam keluarga seperti terlalu memanjakan anak, tidak memberikan pendidikan seks sedini mungkin, penolakan terhadap eksistensi anak bisa menjadi penyebab perilaku seks sebelum menikah.

\section{Kemajuan Teknologi}

Dampak keterbukaan informasi dalam era globalisasi baik melalui media cetak maupun elektronik yang semakin canggih telah menyebabkan pergeseran nilai-nilai budaya, moral dan spiritual. Kemajuan teknologi terutama media elektronik dan media massa menyajikan beragam informasi tentang hal-hal yang bisa memengaruhi perilaku negatif bagi masyarakat secara khusus generasi muda. Alat teknologi seperti internet, handphon dan aplikasi media lainnya menjadi sarana untuk bisa mengakses hal-hal yang berkaitan dengan seksual sulit untuk dibendung, pada akhirnya telah menimbulkan hal yang negatif seperti mengakses hal-hal yang berbau pornografi. ${ }^{60}$ Dengan demikian, tidak bisa dibantah bahwa teknologi telah mempengaruhi seluruh aspek kehidupan manusia mulai dari pola pikir, moral, tingkah laku termasuk perilaku seksual dan salah satu akibatnya ialah terjadinya perilaku hubungan seks sebelum menikah.

\section{Dampak Seks Sebelum Menikah}

\section{Dampak Spiritual}

\section{Berada Dalam Kuasa Dosa}

Secara universal manusia hidup dalam gelimang dosa (Roma 3:23). Alkitab mengemukakan bahwa hubungan seksual diluar pernikahan kudus adala dosa perzinahan (Keluaran 2:14; Matius 5:28). Semua yang berbuat dosa tidak kuasa untuk melepaskan diri dari dosa, karena upah dosa adalah maut (Rm. 6:23). Upah dosa adalah maut mengandung makna seseorang tesebut kehilangan kebahagiaan abadi di Surga. Dosa telah berkusa untuk menghukum dan membinasakannya. Perbuatan seks sebelum menikah merupakan kejatuhan dalam dosa seksual yaitu perzinahan atau percabulan. Maka, ia harus mengalami pemulihan secara total di dalam Yesus Kristus, jika tidak dia berhadapan dengan hukuman maut.

\section{Menjauh Dari Persekutuan}

Pada saat manusia pertama jatuh dalam dosa mata mereka menjadi terbuka dan mereka tahu bahwa, mereka telanjang (Kejdian 3:7). Mereka berusaha

${ }^{60}$ H. Robert Lauer, Perspektif Tentang Perubahan Sosial, (Jakarta: Rineka Cipta, 1993), 220231 
menyembunyikan rasa malu dengan menutupi auratnya menggunakan daun pohon ara serta melarikan diri dari hadapan Tuhan (Kejadian 3:8). Dosa menyebabkan rasa bersalah, rasa malu serta meyalahkan diri sendiri. Sehingga seseorang yang diketahui berbuat dosa dia berusaha menarik diri dari persekutuan dengan Allah dan sesama. Perzinahan adalah aib yang menyebabkan rasa malu yang besar baik terhadap dirinya sendiri, orangtua dan kerabat. Disebabkan karena rasa malu tersebut seseorang yang jatuh dalam dosa seksual memilih keluar dari persekutuan orang percaya dan mundur dari pelayanan gereja.

\section{Dampak Psikologis}

\section{Stres Emosi}

Seks sebelum menikah dapat menyebabkan stres emosi, ketidak percayaan, penyesalan dan kekosongan. Hubungan seks sebelum nikah bisa merusak mental terutama pada perempuan. Perempuan lebih peka dengan emosinya, perempuan juga lebih peka terhadap perasaan-perasaan cemasnya. Secara kognitif perempuan memang memiliki keunikan dan berlainan dengan pria, yakni cenderung melihat hidup atau peristiwa yang dialaminya secara detil. Akibatnya perasaannya tertekan, sulit berkosentrasi dan frustasi.

\section{Rasa Takut}

Rasa takut merupakan suatu perasaan yang menyakitkan, seperti kegelisahan, kebingungan, kecemasan, kegalauan, kekuatiran dan sebagainya, yang berhubungan dengan aspek subyektif emosi. Seseorang perempuan yang melakukan hubungan seks sebelum menikah, ada rasa ketakutan yang sangat besar. ${ }^{61}$ Takut karena merasa berdosa, takut ditolak orangtua, taku mendapat hukuman, takut hamil, takut kehilangan masa depan. Terlebih lagi rasa takut jika calon suaminya tidak setia kepadanya atau tidak bertanggung jawab atas perbutannya.

\section{Memiliki Konsep Seks Yang Salah}

Perilaku hubunga seks sebelum meniikah bisa saja mengubah cara pandang seseorang tentang seks selamanya. Seks seharusnya sesuatu yang sakral dan menjadi sangat indah jika dilakukan oleh pasangan suami istri, tetapi jika dilakukan sebelum menikah, maka bisa jadi seks dipandang sebagai suatu yang kotor, menjijikkan, takut dan terlarang.

\footnotetext{
${ }^{61}$ Andik Wijaya, Sexual Holiness Vol. 4, (Surabaya: Kenza Publising House, 2014), 184-185
} 


\section{Dampak Fisik Dan Kesehatan}

\section{Tidak Virgin}

Istilah virgin berasal dari bahasa Latin "virgo" yang berarti: gadis, perawan. Istilah ini juga punya kaitan erat dengan istilah virga yang artinya baru, ranting muda atau cabang yang belum berbentuk. ${ }^{62}$ Virgin adalah seorang gadis atau perawan yang belum pernah melakukan hubungan seksual, suci atau bersih dan belum pernah di sentuh ataupun dijamah oleh lawan jenisnya. Pada wanita keperawanan ditandai dengan masih utuhnya selaput dara atau selaput dara belum robek. Keperawanan adalah hal yang paling berharga didalam diri seorang perempuan. Seorang wanita yang melakukan hubungan seks sebelum menikah dia kehilangan keperawanannya sebelum waktunya. Konsep diri menjadi rusak sehingga memadang dirinya hina, tidak berguna dan rendah diri.

\section{Hamil}

Kosekuensi logis dari hubungan seksual ialah kehamilan. Kehamilan adalah serangkaian proses yang dialami oleh perempuan yang diawali dengan pertemuan antara sel telur dan sel sperma di dalam indung telur (ovarium) wanita, lalu berlanjut ke pembentukan zigot, perlekatan atau menempel di dinding rahim, pembentukan plasenta, dan pertumbuhan serta perkembangan hasil konsepsi sampai cukup waktu.

Berdasarkan penelitian dari Australian National University (ANU) dan Pusat Penelitian Kesehatan Universitas Indonesia (UI) tahun 2010-2011 di Jakarta, Tangerang dan Bekasi (Jatabek) dengan jumlah sampel 3006 responden (usia 17-24 tahun), menunjukkan $20.9 \%$ remaja mengalami kehamilan dan kelahiran sebelum menikah. Kemudian 38,7 persen remaja mengalami kehamilan sebelum menikah dan kelahiran setelah menikah. Dari data tersebut terdapat proporsi yang relatif tinggi pada remaja yang melakukan pernikahan disebabkan oleh karena kehamilan yang tidak diinginkan.

\section{Aborsi}

Istilah aborsi (bahasa Latin: abortus) adalah berakhirnya kehamilan dengan dikeluarkannya janin (fetus) atau embrio sebelum memiliki kemampuan untuk bertahan hidup di luar rahim, sehingga mengakibatkan kematiannya. Aborsi merupakan tindakan untuk mengakhiri kehamilan dengan pengeluaran hasil konsepsi sebelum janin dapat hidup diluar kandungan. Berdasarkan data dari Komisi Perlindungan Anak Indonesia (KPAI) tahun 2013, diketahui sebanyak 32\% remaja usia 14 hingga 18 tahun di kota besar di Indonesia (Jakarta, Surabaya, dan Bandung) pernah berhubungan seksual pranikah dan membuktikan $62,7 \%$ remaja perempuan kehilangan perawan saat masih duduk di bangku SMP, bahkan 21,2\% diantaranya

\footnotetext{
${ }^{62}$ https://www.evitworld.blogspot.com, (On Line: Selasa, 12 Maret 2018)
} 
ekstrim, yakni pernah melakukan aborsi. ${ }^{63}$ Tindakan aborsi pilihan yang paling banyak dilakukan oleh para perempuan yang hamil akibat melakukan hubungan seks sebelum menikah. Motif aborsi untuk menyembunyikan rasa malu dan aib akibat perbuatannya.

\section{Penyakit Menular Seksual (PMS)}

Resiko yang lain dari melakukan hubungan seks sebelum menikah ialah Penyakit Menular Seksual (PMS). Penyakit Menular Seksual dapat berujung pada penyakit reproduktif mengerikan dan berbahaya bagi kesehatan terlebih dapat membahayakan sistem imunitas tubuh seperti menyebabkan gonorhoe (penyakit kencing nanah), sifilis (raja singa), kutil kelamin, keputihan, kanker servic, kanker prostat, herpes genitalis, Aquired Immuno Deficiency Syndrome (AIDS), dan lain sebagainya. Bahkan seseorang yang menderita salah satu PMS tersebut dapat menyebabkan kemandulan (infertil) atau jika seseorang terkena penyakit sifilis dan gonorhoe akut pada pria dapat membuat alat vital (penis) meradang dan penis rusak, impotensi, bahkan penis dapat hilang. ${ }^{64}$ Dengan demikian, perilaku seks sebelum menikah sangat beresiko pada kesehatan baik laki-laki maupun perempaun.

\section{Dampak Sosial}

Perilaku seks sebelum menikah memiliki dampak sosial. Menurut etika sosial budaya bahwa seks sebelum menikah merupakan perilaku asusila atau amoral yang menyebabkan relasi negatif dari masyarakat lingkungan. Perbuatan asusila tersebut menjadi bahan membicaraan yang hangat dilingkungan tempat tinggal misalnya tetangga, teman, sahabat, kerabat dan masyarakat lainnya. Hal ini akan menimbulkan rasa malu yang besar bagi pelaku sehingga tidak mau bertemu dan bergaul kepada kepada orang lain biasanya memilih untuk mengurung diri atau menjauh dari komunitas. Dampak sosial lainnya pelaku bisa saja mendapat penghakiman atau kekerasan dari masyarakat lingkungan.

\section{Dampak Bagi Keluarga}

\section{Anak}

Fakta menunjukkan bahwa perilaku seks sebelum menikah menyebabkan terjadinya hamil di luar nikah. Peneliti sendiri menemukan beberapa pasangan melangsungkan pernikahan mereka disaat mempelai perempuan sedang dalam kondisi hamil. Pada umumnya semua pasangan merindukan kehadiran seorang anak di dalam keluarga mereka, untuk melengkapi sukacita dan kebahagiaan dalam mengarungi bahtera rumah tangga. Namun tidak bisa dipungkiri ada orangtua yang

\footnotetext{
${ }^{63}$ https://www.eprints.ums.ac.id, (On Line: Rabu, 14 Maret 2018)

${ }^{64}$ Ronal Hutapea, AIDS, PMS dan Pemerkosaan, (Jakarta: Rineka Cipta, 2014), 63-64
} 
tidak menginginkan kehadiran anaknya salah satu penyebabnya karena hamil di luar pernikahan. Secara psikologis anak yang akan dilahirkan sudah tertolak sejak dalam kandungan. Anak yang diperoleh di luar pernikahan, jika tidak mendapatkan pembimbingan yang baik mereka akan membenci dirinya sendiri, kecewa dengan orang tuanya bahkan ada kemungkinan melakukan pelanggaran yang sama seperti orangtuanya.

\section{Suami}

Hubungan suami-istri dibangun berdasarkan rasa kagum, kasih sayang, cinta, percaya dan kejujuran. Diantara keduanya harus saling mengagumi serta mempertahankan kepercayaan satu sama lain. Bagi pasangan yang telah melakukan hubungan seksual sebelum menikah akan muncul masalah dikemudian hari. Khususnya bagi suami timbul sikap kurang menghargai dan merendahkan pasanganya. ${ }^{65}$ Kegagalan dimasa lalu juga bisa mengakibatkan suami mengalami trauma dengan istrinya sehingga menimbulkan pikiran negatif seperi kurang percaya, curiga dan rasa cemburu yang berlebihan.

\section{Lingkup Pernikahan Kristen}

\section{Pengertian pernikahan}

Menurut Kamus Besar Bahasa Indonesia (KBBI) kata "pernikahan" adalah hal (perbuatan) nikah, upacara nikah (ikatan/akad perkawinan yang dilakukan sesuai dengan ketentuan hukum dan ajaran agama). ${ }^{66}$ Hukum Indonesia mendefenisikan pernikahan adalah ikatan lahir batin antara seorang pria dan seorang wanita sebagai suami istri dengan tujuan membentuk keluarga yang bahagia dan kekal berdasarkan Ketuhanan Yang Maha Esa. ${ }^{67}$ Sedangkan menurut iman Kristen pernikahan adalah persekutuan yang ekslusif seumur hidup antara seorang pria dan seorang wanita atau satu komitmen antara seorang laki-laki dan perempuan yang melibatkan hak-hak seksual secara timbal balik. ${ }^{68}$ Dengan demikian, pernikahan adalah sebuah keputusan antara seorang laki-laki dan seorang perempuan untuk membentuk satu keluarga yang baru didasarkan pada hukum dan takut akan Tuhan serta diikat dalam janji nikah bahwa setia hidup berdua untuk selamanya.

\footnotetext{
${ }^{65}$ Andik Wijaya, Sexual Holiness Vol. 4..., 184-185

${ }^{66}$ Hasan Shadily, Kamus Besar Bahasa Indonesia, (Jakarta: Balai Pustaka, 2000), 232

${ }^{67}$ Undang-Undang Nomor 1 Tahun 1974 Pasal 1

${ }^{68}$ J.L. Ch. Abineno, Seksualitas dan Pendidikan Seksual, (Jakarta: BPK Gunung Mulia, 2012),
} 


\section{Dasar Alkitab Pernikahan Kristen}

\section{Perjanjian Lama (PL)}

Dasar penikahan dalam Perjanjian Lama (PL) pertama sekali dijelaskan dalam kitab Kejadian pasal 1 dan 2. Kejadian 2: 18-25 Menurut ayat ini pernikahan adalah rancangan Allah bagi manusia. Tuhan Allah berfirman: "Tidak baik, kalau manusia itu seorang diri saja. Aku akan menjadikan penolong baginya, yang sepadan dengan dia" (Kejadian 2:18). Allah memperhatikan benar bahwa manusia tidak dapat hidup sendiri dan memerlukan penolong yang sepadan dengan dirinya. Allah menciptakan laki-laki dan perempuan serta menyatukan mereka bersama dalam pernikahan (Kejadian 1:27-28). Pernikahan merupakan gagasan dari Allah, itu sebabnya setiap orang percaya selaknya memakai Alkitab untuk menjelaskan arti pernikahan dan keluarga.

Demikian juga kitab Imamat 18: 1-30 dan 20: 1-27 memberikan penekanan bahwa dasar pernikahan itu diatur dalam hukum-hukum dan peraturan yang sangat ketat di mana orang Israel diperingatkan secara keras supaya mereka jangan menjadi serupa dengan cara kehidupan orang-orang asing yaitu Kanaan dan Mesir. Peraturan itu antara lain berisi tekanan bahwa hubungan seksual dilarang di antara kerabat dekat, hubungan dengan perempuan pada waktu camar kainnya yang menajiskan, zinah, hubungan homoseks serta hubungan dengan binatang karena hal itu keji dan menajiskan orang dan kekudusan nama Allah dilanggar. ${ }^{69}$ Oleh karena itu, pernikahan ada atas inisiatif Allah suapaya manusia hidup bahagia bersama suami atau istrinya, namun pernikahan yang dikehendaki Allah adalah pernikan yang didasari atas kebenaran firman Tuhan.

\section{Perjanjian Baru (PB)}

Sebagaimana ungkapan Tuhan Yesus Matius 19:4-6 "Sebab itu laki-laki akan meninggalkan ayah dan ibunya dan bersatu dengan isterinya, sehingga keduanya menjadi satu daging. Demikianlah mereka bukan lagi dua, melainkan satu. Karena itu apa yang telah disatukan Allah, tidak boleh diceraikan manusia." Kebenaran firman Tuhan ini adalah dasar dari pernikahan Kristen. Pernikahan bukanlah ide manusia melainkan merupakan inisiatif Allah. Semua yang diciptakan Allah adalah baik termasuk pernikahan yang adalah juga baik dalam rancangan-Nya. Namun ketika manusia berbuat diluar rancangan-Nya itu, dosa masuk sehingga pernikahan mengalami kerusakan. ${ }^{70}$ Rasul Paulus mengajarkan bahwa dasar pernikahan adalah kasih Kristus. Sebab hubungan suami istri adalah gambaran hubungan Kristus dengan jemaat (Efesus 5:22-23).

\footnotetext{
2003), 180

${ }^{69}$ Chritopher Wright, Hidup Sebagai Umat Allah Etika PL, (Jakarta: BPK Gunung Mulia,

${ }^{70}$ Volkhard dan Gerlinde Scheunemann, Hidup Sebelum \& Sesudah Menikah, (Batu: Literatur YPPII, 2018), 29-30
} 


\section{Ciri Pernikahan Kristen}

\section{Pernikahan Kristen Adalah Rancangan Allah}

Pada awal penciptaan manusia Allah sudah mempunyai rencana agar laki-laki dapat bersatu dengan perempuan untuk tujuan saling melengkapi dan beranak cucu memenuhi bumi. ${ }^{71}$ Firman Allah dalam Kejadian 2:18, "Tuhan Allah berfirman: tidak baik kalau manusia itu seorang diri saja, Aku akan menjadikan penolong baginya, yang sepadan dengan dia." Kemudian Kejadian 1: 28, "Allah memberkati mereka, lalu Allah berfirman kepada mereka: Beranak-cuculah dan bertambah banyak; penuhilah bumi dan taklukanlah itu, berkuasalah atas ikan-ikan di laut dan burungburung di udara dan atas segala binatang yang merayap di bumi." Teks firman Tuhan tersebut memberi makna bahwa Tuhan menghendaki manusia memilik pasangan (suami-istri) yang diberkati dalam pernikahan kudus, agar manusia dari generasi ke generasi berikutnya menjadi perpanjangan tangan Allah untuk memelihara dan mengusahakan bumi.

\section{Pernikahan Kristen Adalah Kudus}

Perkawinan Kristen adalah sesuatu yang kudus di mata Allah itulah sebabnya Allah menganggap dosa bagi mereka yang mencerminkan ikatan pernikahan dengan melakukan perzinahan (Im. 18,19, 20; Kis. 15:20; 1 Kor. 6:18; Kel. 20:14). Firman Tuhan tertulis dalam Ibrani 13:4, "Hendaklah kamu semua penuh hormat terhadap perkawinan dan janganlah kamu mencemarkan tempat tidur, sebab orang-orang sundal dan penzinah akan dihakimi Allah". Penulis kitab Ibrani juga kembali menegaskan bahwa perkawinan itu adalah sesuatu yang kudus dan tidak boleh dicemarkan. ${ }^{72}$ Di dalam kitab Maleakhi dijelaskan bahwa maksud Allah dengan menjadikan manusia adalah untuk menghasilkan keturunan yang ilahi (Mal. 2:15). Pernikahan Kristen adalah sesuatu yang kudus di hadapan Allah. Oleh karena itu, Allah menganggap suatu dosa bagi mereka yang mencemarkan ikatan pernikahan, bahkan hubungan seksual sebelum menikah maupun hubungan seksual sebagai perselingkuhan dianggap sebagai perzinahan.

\section{Pernikahan Kristen Adalah Permanen}

Alkitab menuliskan bahwa kehendak Allah adalah pernikahan sebagai komitmen seumur hidup atau bisa disebut permanen. Kebenaran ini dengan jelas dan tegas dikatakan oelh Tuhan Yesus, "Apa yang telah dipersatukan Allah, tidak boleh diceraikan manusia" (Matius 19:6). Jadi Allah dari sejak semula menetapkan bahwa pernikahan sebagai ikatan yang permanen, yang berakhir hanya ketika salah satu

${ }^{71}$ Donald Guthrie, Tafsiran Alkitab Masa Kini I, Kejadian-Ester, (Jakarta: Yayasan Bina Kasih OMF, 2005), 85

\footnotetext{
${ }^{72}$ Volkhard dan Gerlinde Scheunemann, Hidup Sebelum..., 31-32
} 
pasangannya meninggal (Roma 7:1-3; 1 Korintus 7:10-11). ${ }^{73}$ Paulus juga menegaskan hal ini ketika ia berkata "Sebab seorang isteri terikat oleh hukum kepada suaminya selama suaminya itu hidup. Akan tetapi apabila suaminya itu mati, bebaslah ia dari hukum yang mengikatnya kepada suaminya itu. Jadi, selama suaminya hidup ia dianggap berzinah, kalau ia menjadi isteri laki-laki lain; tetapi jika suaminya telah mati, ia bebas dari hukum, sehingga ia bukanlah berzinah, kalau ia menjadi isteri lakilaki lain" (Roma 7:2-3).

\section{Tujuan Pernikah Kristen}

\section{Procreation}

Sejak penciptaan, Tuhan telah memberikan perintah kepada manusia "Beranak cuculah dan bertambah banyak, penuhilah bumi dan taklukkanlah itu, berkuasa atas ikan-ikan di laut dan burung-burung di udara dan atas segala bidatang merayap di bumi"' (Kejadian 1:28). Sebelum Allah mengucapkan perintah tersebut, Allah telah melengkapi manusia dengan organ-organ reproduksi yang memungkinkan mereka untuk bereproduksi. ${ }^{74}$ Tuhan memberikan perintah kepada manusia untuk berkembangbiak memenuhi seluruh bumi. Allah punya tujuan dalam pernikahan supaya manusia itu melahirkan generasi yang takut akan Tuhan dan perkasa di bumu ini. Oleh karena itu, lewat kehadiran anak-anak dalam keluarga yang takut akan Tuhan melalui prokreasi akan mempermudah proses pencapaian visi Allah lintas generasi.

\section{Partnership}

Tujuan yang lain Allah menciptakan pernikahan ialah supaya laki-laki dan perempuan menjadi partnership (mitra) dalam menjalani kehidupan rumah tangga. Kejadian 2:22, "Lalu Tuhan Allah membuat manusia itu tidur nyenyak, ketika ia tidur, Tuhan Allah mengambil salah satu rusuk dari padanya, lalu menutup tempat itu dengan daging. Dan dari rususk yang diambil Tuhan Allah dari manusia itu, dibangun-Nyalah seorang perempuan, lalu dibawa-Nya kepada manusia itu." Karena Tuhan mengambil tulang rusuk Adam maka ada sesuatu yang kurang dari diri Adam, sampai yang diambil dari Adam itu dibawa lagi kepada Adam supaya mereka menjadi satu. Ketika seorang pria bersatu dengan istrinya, saat itu ada penyatuan yang membuat keduanya menjadi pribadi yang lengkap dan berfungsi maksimal. ${ }^{75}$ Oleh karena itu, pernikahan ditetapkan Allah supaya suami-istri akan saling melengkapi dan saling menyempurnakan.

\footnotetext{
${ }^{73}$ David Egner, Krikil-krikil Tajam Pernikahan, (Jakarta: Duta Harapan, 2014), 22-23

${ }^{74}$ Andik Wijaya, Sexual Holiness Vol. 1..., 90

${ }^{75}$ Andik Wijaya, Sexual Holiness Vol. 3 ..., 32
} 


\section{KESIMPULAN}

Pertama, Pelayanan pastoral konseling merupakan pelayanan yang efektif untuk memahami dan menolong jemaat dalam setiap persoalan mereka. Secara khusus para hamba Tuhan harus memberikan pelayanan pastoral konseling bagi jemaat yang memiliki pergumulan khusus salah satunya bagi perempuan yang telah melakukan hubungan seks sebelum menikah, supaya jemaat dikuatkan, jiwanya diselamatkan dan mengalami pemulihan di dalam Tuhan. Dalam melakasankan pastoral konseling bagi perempuan yang telah melakukan hubungan seks sebelum menikah perlu menggunakan pendekatan psikologis Alkitabiah. Psikologi Alkitabiah dapat diterapkan para konselor Kristen untuk memudahkan memahami pikiran, perasaan dan keadaan yang sedang dialami konseli. Maka, psikologi berguna sebagai prinsip pendekatan supaya konseli dapat lebih terbuka, sehingga tujuan pastoral konseling itu sendiri dapat tercapai.

Kedua, Perempuan merupakan ciptaan Tuhan yang mulia, berharga dan istimewa di hadapan Allah. Perempuan juga memiliki natur segambar dan serupa dengan Allah sehingga perempuan sehakikat dengan laki-laki. Tuhan menciptakan perempuan memiliki peranan sebagai penolong bagi suami, mengajarkan kebenaran kepada anak dan memberikan hidup untuk melayani Tuhan. Kemudian seks adalah merupakan ciptaan Tuhan yang baik bagi manusia. Tuhan punya tujuan menciptakan seks bagi manusia agar manusia memiliki keintiman, satu keastuan dan kenikmatan. Seks yang berkenan kepada Allah ialah hubungan seksual yang dilakukan oleh pasangan suami-istri yang sudah diberkati dalam pernikahan kudus. Seks menurut Alkitab memiliki dimensi prokreasi, dimensi relasi, dimensi rekreasi dan dimensi refleksi. Namun, fakta membuktikan bahwa seks seringkali dipahami secara salah oleh sebagian manusia. Kosekuensi logis dari pemahaman seks yang salah akan menimbulkan hubungan seksual yang terlarang misalnya hubungan seks sebelum menikah. Secara khusus perempuan melakukan hubungan seks sebelum menikah, memiliki beberapa faktor diantaranya pertumbuhan biologis, pacaran, pelecehan seksual, teknologi dan sebagainya. Perilaku hubungan seks sebelum menikah akan berdapak terhadap spritual, psikologi, fisik dan sosial.

Ketiga, Kasus perempuan yang telah melakukan hubungan seks sebelum menikah adalah dosa yang sangat serius di hadapan Tuhan. Tuhan tidak menginzikan hubungan seksual di luar penikahan kudus. Dosa seks sebelum menikah mengakibatkan seseorang berstatus manusia berdosa di hadapan Allah. Perempuan yang telah melakukan hubungan seks sebelum menikah permasalahannya bisa diselesain dengan metode pastoral konseling yang tepat. Berdasarkan hasil temuan penelitian di lapangan mengenai faktor dan dampak hubungan seks sebelum memikan, maka cara untuk menyelesaikan kasus tersebut dengan menerapkan model pastoral konseling psikologi Alkitabiah bagi perempuan yang telah melakukan hubungan seks sebelum menikah 


\section{Daftar Pustaka}

Abineno, J.L. Ch

2012 Seksualitas dan Pendidikan Seksual, Jakarta: BPK Gunung Mulia Boy, Soedarmadji \& Hartono

2014 Psikologi Konseling, Jakarta: Kencana Prenada Media Group

Browning, W.R.F

2008 Kamus Alkitab, Jakarta: BPK Gunung Mulia

Clinebell, Howard

2006 Tipe-tipe Dasar Pendampingan \& Konseling Pastoral, Jakarta:

Collins, Gary R

1998 Konseling Kristen Yang Efektif, Malang: SAAT

Corey, Gerald

BPK Gunung Mulian

2007 Teori Dan Praktek Konseling Dan Psikoterapi, Bandung: Refika Aditama

Crabb, Larry

$2011 \quad$ Konseling Yang Efektif Dan Alkitabiah, Yogyakarta: Andi

Diniati, Amira

2009 Teori-teori Konseling, Pekanbaru: Daulat Riau

Douglas, J. D

2008 Ensiklopedia Alkitab Masa Kini I \& II Jakarta: Yayasan

Giri, Wiarto

2015 Psikologi Perkembangan Manusia, Yokyakarta: Psikosain

Gulo \& Kartini, Kartono

1987 Kamus Psikologi, Bandung: CV. Pioner Jaya

Guthrie Donald

2005

Tafsiran Alkitab Masa Kini I, Kejadian-Ester, Jakarta: Yayasan Bina Kasih OMF

Hartono

2014 Psikologi Konseling, Jakarta: Kencana Predana Media Group

Hidayat, Dede Rahmat

2011 Teori Dan Aplikasi Psikologi Kepribadian Dalam Konseling, Bogor: Ghalia Indonesia

Hunt, June

2008 Kebenaran Alkitab Menjawab Masalah Anda 2, Denpasar: Hope For The Heart Indonesia

Hutapea, Ronal

2014

AIDS, PMS dan Pemerkosaan, Jakarta: Rineka Cipta

Johnson, Eric L

2002 Psycology \& Christiaty, Jakarta: BPK Gunung Mulia 
Missio Ecclesiae, 7(2), Oktober 2018, 287-317

Lauer, H. Robert

1993 Perspektif Tentang Perubahan Sosial, Jakarta: Rineka Cipta

Lois, Edwin

nd Wanita Unik, Jakarta: Yayasan Pekabaran Injil "Imanuel"

Mayo, Mary Ann

1986 Pendidikan Seks Dari Orangtua Kepada Anak, Bandung: Yayasan Kalam Hidup

Meiler, Paul D 2004 Pengantar Psikologi \& Konseling Kristen 2, Yokyakarta: Andi Miles, Herbert J

1983 Seks Sebelum Pernikahan, Jakarta: BPK Gunung Mulia

Oetomo, Dede

2005 Penelitian Kualitatif: Aliran Dan Tema, Metode Penelitian Sosial:

Berbagai Alternatif Pendekatan, Diedit Oleh: Bagong Suyanto, Jakarta: Kencana Prenada Media Grouap

Rahman, Hibana S

2003 Bimbingan Konseling Pola 17, Yogyakarta: UCI Press Surya

\section{Internet}

https://www.evitworld.blogspot.com, 12 Maret 2018

https://www.eprints.ums.ac.id, 14 Maret 2018

https://www.kupastuntas.co, 21 Maret 2018

https://www.scribd.com, 21 Maret 2018

https://id.wikipedia.org/wiki/Kepolisian_Lampung, 7 April 201 